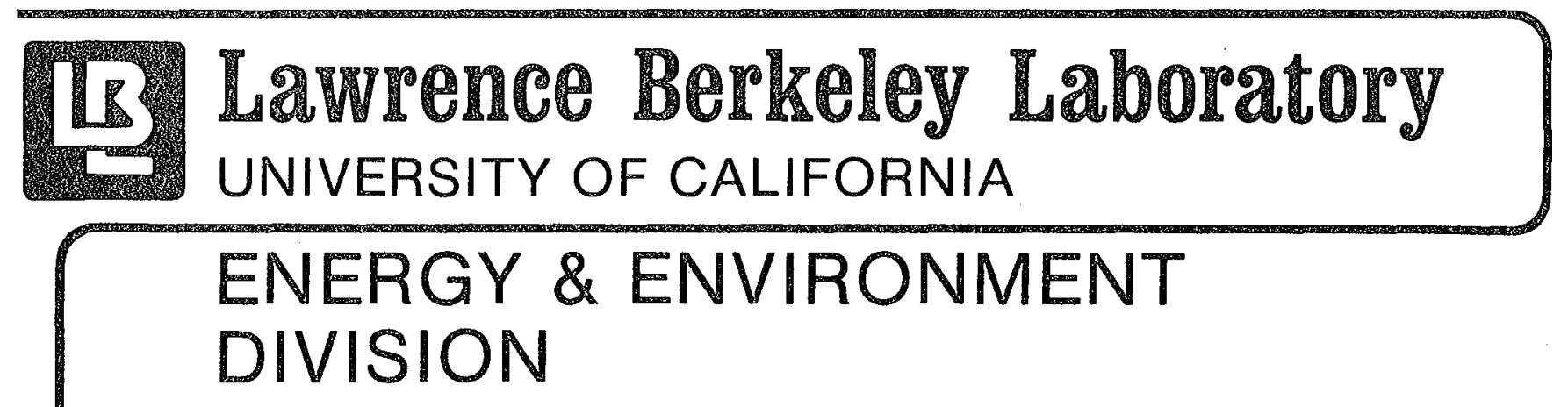

Submitted to Indoor Air

Meteorological Database for the United States

M.G. Apte, A.V. Nero, and K.L. Revzan

April 1996

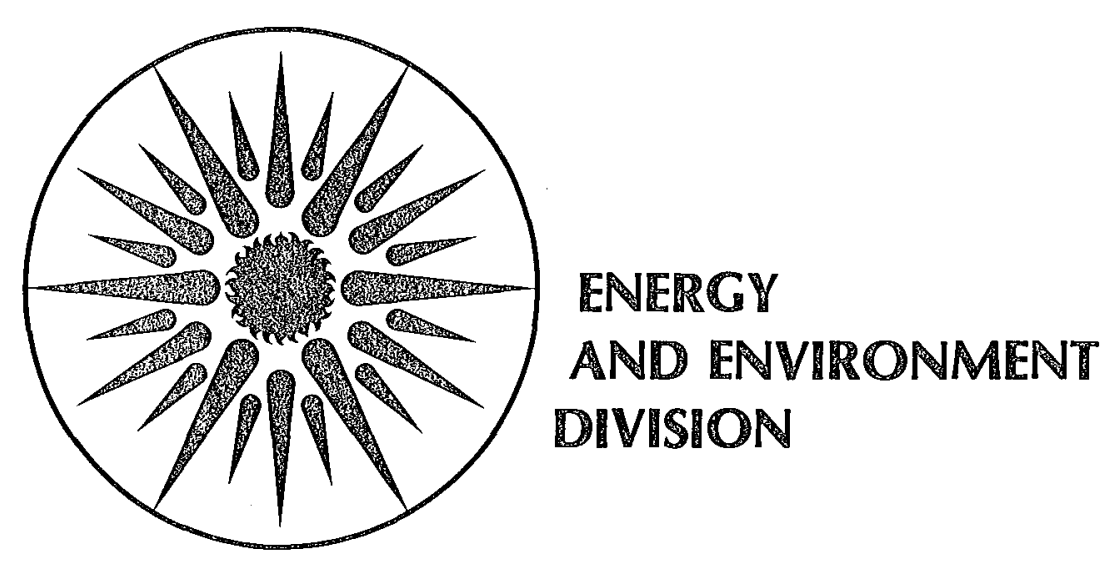

万人

욱ำ

$\rightarrow \sum \frac{8}{2}$

$\sum \stackrel{0}{2}$

蛋菖

的 $<$

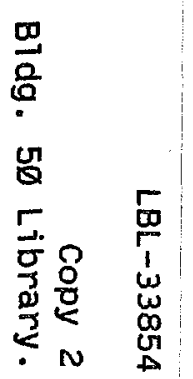




\section{DISCLAIMER}

This document was prepared as an account of work sponsored by the United States Government. While this document is believed to contain correct information, neither the United States Government nor any agency thereof, nor The Regents of the University of California, nor any of their employees, makes any warranty, express or implied, or assumes any legal responsibility for the accuracy, completeness, or usefulness of any information, apparatus, product, or process disclosed, or represents that its use would not infringe privately owned rights. Reference herein to any specific commercial product, process, or service by its trade name, trademark, manufacturer, or otherwise, does not necessarily constitute or imply its endorsement, recommendation, or favoring by the United States Government or any agency thereof, or The Regents of the University of California. The views and opinions of authors expressed herein do not necessarily state or reflect those of the United States Government or any agency thereof, or The Regents of the University of California.

Ernest Orlando Lawrence Berkeley National Laboratory

is an equal opportunity employer. 
LBL-33854

UC-402

\title{
Meteorological Database for the United States
}

\author{
M.G. Apte, A.V. Nero, and K.L. Revzan \\ Indoor Environment Program \\ Energy and Environment Division \\ Ernest Orlando Lawrence Berkeley National Laboratory \\ University of California \\ Berkeley, California 94720
}

April 1996

This work was supported by the U.S. Environmental Protection Agency through Interagency Agreement DW89935055-01-5 with the Department of Energy (DOE). This work was also supported by the Director, Office of Energy Research, Office of Health and Environmental Research, Health Effects and Life Sciences Research Division of DOE under Contract No. DE-AC03-76SF00098. 



\section{Abstract}

A meteorological database has been developed to aid in the prediction of indoor radon concentrations in the United States. The database contains predicted typical monthly meteorological statistics at the county level derived from hourly meteorological data from 208 (234 for precipitation) geographically distinct monitoring stations. Interpolation and extrapolation techniques were used to predict statistics for counties not containing a meteorological monitoring site. The LBNL database includes statistics for meteorological variables including dry-bulb temperature, dew-point temperature, barometric pressure, wind speed, wind direction, hours of precipitation, precipitation, and derived infiltration degree-days. The database consists of individual files of derived statistics for each weather variable and is potentially useful for indoor radon modeling as well as for other purposes. Each file contains data values for all 12 months and an aggregation of the 12 months up to a yearly statistic for all county centroids. A test was conducted to assess the quality of interpolated values. Examples showing the use of the database for mapping infiltration degree-days and an application of the database to a statistical correlation analysis attempting to find meteorological factors influencing indoor radon levels in the United States is discussed.

\section{KEY WORDS:}

Meteorology, Infiltration degree days, Indoor air quality, Database, Modeling, Radon, U.S., World Wide Web 



\section{Introduction}

Indoor radon concentrations among U.S. homes vary substantially from one area of the country to another (Nero, 1986). For more than a decade it has been recognized that most of the radon in homes arises from flow of soil gas from underlying soil or rock into home interiors (Nero, 1984), driven primarily by indooroutdoor temperature differences, winds, and sometimes operation of heating or cooling systems. Much of the work on modeling the variability of indoor concentrations, either physically or statistically, has therefore been directed to investigating the influence of soil radium content, of the permeability of the soil structure to the transport, entry or removal of radon-bearing air, and of the meteorological variables providing the driving forces (Nazaroff; 1988).

Substantial efforts have been made to model the physical processes accounting for radon entry into houses. In recent years attempts have been made to examine the power of regional statistical models, i.e., those relating measured indoor concentrations with available data on physical factors, to provide estimates of local indoor radon concentrations within a region (Nero, 1994, Price et al., 1995). These efforts indicate the substantial power of, for example, radium data to indicate county geometric mean indoor radon concentrations. Lawrence Berkeley National Laboratory (LBNL), in cooperation with the U.S. Geological Survey (USGS) and others, is attempting to examine methods to incorporate a more complete set of data in such models. As part of this effort, an attempt has been made to utilize data from the National Residential Radon Survey, conducted in 1989-91 for the U.S. Environmental Protection Agency (Marcinowski, 1994), to examine the correlation, on a national basis, between indoor radon concentrations and soil, structural, and meteorological data.

A number of meteorological databases are available for the United States, but few contain the full range of information of interest from the point of view of building ventilation and indoor air quality. One database, developed some years ago at LBNL, uses meteorological data as a basis for calculating "infiltration degree days" (IDD), a variable related to air infiltration into buildings. This metric, analogous to the more familiar heating or cooling degree days, is used to indicate infiltration-induced energy loads for heating and cooling (ASHRAE, 1988 and Sherman, 1986). In the present work, an analogous course has been taken to develop a database of primary meteorological variables, as well as derived variables such as 
the IDD, for use in development of a national correlation model for indoor radon concentrations. These data, provided for each county in the contiguous 48 states may also have application to other indoor-airquality modeling problems, as well as in other areas where meteorological factors are of interest. The database is available to the scientific community via the World Wide Web and anonymous file transfer protocol (FTP) on the internet.

\section{Methods}

The database contains monthly summary statistics of hourly data by U.S. county, derived through interpolation and extrapolation from two data sets available to the public from the National Oceanic and Aeronautic Administration: the typical meteorological year (TMY) file set (NOAA, 1981) and the 30-year Climatological Normals (CCD, NOAA, 1991). The TMY file set is a compilation of hourly measurements of meteorological variables from different months over the period of January, 1953 through December, 1975, selected to be typical of each month. Precipitation data were derived from the CCD file for precipitation.

\section{TMY Data}

Hourly data from 208 TMY weather stations in the contiguous 48 states of the U.S. were aggregated to yield monthly statistics. Table 1 lists the monthly statistics computed for each weather variable. These statistics include monthly arithmetic mean and standard deviation, daytime arithmetic mean and standard deviation, nighttime arithmetic mean and standard deviation, diurnal swing arithmetic mean and standard deviation, maximum, minimum, and average hourly swing. Additionally, monthly counts of wind directionhours are reported for 8 octants (north, northeast, east, southeast, south, southwest, west, and northwest); monthly infiltration degree-days (IDD), monthly heating IDD, monthly cooling IDD, monthly counts of hours of rain, hours of snow, hours of rain-or-snow, and hours of no precipitation (dry) are also reported. IDD was calculated because it is a physical variable representing the degree to which temperature and winds cause infiltration into buildings. This metric might serve as an indicator of ventilation rates and/or radon entry rates. 
Statistical measures computed from the meteorological variables for diurnal swing and average hourly swing are included in Appendix I. Daytime is defined as from 06:00 hr to 18:00 hr. Nighttime is defined from 18:00 hr to 06:00 hr. Each octant reported for the wind direction is defined as wind coming from within an angle of $\pm 22.5^{\circ}$ of that direction. For example the wind direction called North contains hourly wind direction counts for periods when the wind direction was from north-northwest through northnortheast.

IDD is calculated according to the ASHRAE method (ASHRAE, 1988; Sherman, 1986). This quantity has been of interest because it is relates meteorological conditions to the infiltration component of building heating and cooling loads. Infiltration, defined as the air-flow between a building $\left(\mathrm{ft}^{3} / \mathrm{hr} \mathrm{or} \mathrm{m}^{3} / \mathrm{s}\right.$ ) and its exterior, is driven by indoor-outdoor pressure differences caused by wind impingement on building surfaces and indoor-outdoor temperature differences. The calculation of heating IDD includes consideration of wind speed and dry-bulb temperatures. In the case of cooling IDD, wet-buib temperature is also used in order to calculate the latent heat in moisture in the air. Monthly IDD is the sum of monthly cooling and heating IDDs. IDD is similar to the more common degree day (the sum of daily average temperature differences below or above a base temperature, typically $65^{\circ} \mathrm{F}$ for heating and $75^{\circ} \mathrm{F}$ for cooling), except that it is normalized by a factor which accounts for additional energy loads due to infiltration. This factor, as presented in the ASHRAE method, is the ratio of specific infiltration, $s(\mathrm{ft} / \mathrm{hr}$ or $\mathrm{m} / \mathrm{s})$, to average specific infiltration, $s_{0}(8400 \mathrm{ft} / \mathrm{hr}$ or $0.71 \mathrm{~m} / \mathrm{s})$, where:

$s \equiv \sqrt{f_{s}^{2}|\Delta T|+f_{w}^{2} v^{2}}$

and where

$f_{s}=$ stack factor $\left(1056 \mathrm{ft} / \mathrm{hr}^{-}{ }^{0} \mathrm{~F}^{0.5}\right.$ or $\left.0.12 \mathrm{~m} / \mathrm{s}-\mathrm{K}^{0.5}\right)$,

$f_{w}=$ wind factor $(0.132$, dimensionless $)$

$\Delta T=$ indoor - outdoor temperature difference $\left({ }^{\circ} \mathrm{F}\right.$ or $\left.\mathrm{K}\right)$, and

$\mathrm{V}=$ measured wind speed $(\mathrm{ft} / \mathrm{hr}$ or $\mathrm{m} / \mathrm{s})$.

Thus the calculated monthly or yearly IDD reflects the extent to which meteorology effects infiltration. 
Infiltration, being a form of building ventilation, plays an important role in the removal of indoor pollutants from buildings. Furthermore in the context of understanding the mechanisms of entry of a soil gas such as radon into structures, infiltration is particularly important: a depressurized building substructure can lead to an inward flow of soil gas through openings at the soil-house interface (Nero, 1984). Therefore, calculated IDD may be useful in modeling indoor radon concentrations.

\section{CCD Data}

Inches of precipitation are derived from 30-year climatological-normals precipitation data from the CCD data set. This data set contains monthly average precipitation data, including the liquid water equivalent for snowfall. The meteorological database uses data from 234 weather station sites in the contiguous 48 states of the U.S. The only precipitation statistic used is the monthly arithmetic mean, since hourly data were not included in the CCD data set.

\section{Meteorological Data Interpolation and Extrapolation}

To suit the meteorological data needs for modeling indoor radon concentrations at any geographic location in the continental U.S., a bivariate interpolation method was used to create a matrix of interpolated values for each of the statistics for each of the variables described above. The matrix of mapped interpolated values was created to a resolution of 0.1 degree latitude and 0.1 degree longitude. Extrapolations were allowed to points in the matrix exterior to the convex hull of the coordinates of the input data. In order to reduce these data to a usable size, only the interpolated/extrapolated data closest to each county centroid were retained. In other words, the LBNL meteorological database contains estimates for the meteorological statistics in Table 1 at each county centroid in the continental U.S. County centroids were calculated from 1990 U.S. Census TIGER File data (U.S. Bureau of Census, 1991). Since an exact interpolation method was used, original point values are preserved. Therefore, interpolated values for any coordinate which coincides with a TMY or CCD measurement coordinate are identical to the measured data that were used 
for that coordinate. Data at or close to these locations are more reliable than data for a coordinate located at some distance from the meteorological measurement locations.

A test was devised in order to assess the reliability of the method of interpolation for predicting the meteorological statistics for a given variable at a location distant from a measurement site. The test attempts to determine how well measured meteorological variables correlate with the predicted values for the given data set. Since all of the available TMY and CCD data are used as input for the database, no external data were appropriate for the test, short of creating additional "typical" meteorological data for a new location. Instead, data points were removed at random from the set of 208 sites (234 for the CCD data), six sites at a time, and the interpolation was performed without them. The interpolated values for the removed sites were then compared against the actual (expected) values for those sites. The six resulting values were then stored and the process was repeated fifteen more times. All sixteen sets of six pairs of values are combined into a single regression of 96 "actual" values vs. 96 values predicted by interpolation.

Figure 1 presents a selected set of sixteen pairs of data (the lines indicate $x=y$, a perfect correlation), for a variable (dry-bulb temperature) having a relatively "smooth" behavior geographically. Figure 2 presents the combined 96 pairs of data from Figure 1, and the linear least-square best-fit line. If the interpolation were perfect, the slope of the regression line would be one and the intercept would be zero. Additionally, the correlation coefficient $R^{2}$ would be 1.0 .

The results of this test are presented in Table 2 for each meteorological variable and each of its statistics for a single winter month. These results suggest which county variables can be reliably predicted using the interpolation scheme and which should be avoided.

\section{Meteorological Variables Estimated for the EPA National Residential Radon Survey Locations.}

A subset of the database containing the data for counties included in the EPA National Residential Radon Survey (NRRS) was extracted (Marcinowski, 1992). This subset contains all of the statistics for all of the variables in Table 1. The "National Residential Radon Survey - Meteorological Set" (NRRS-MET) contains a record for each of the counties in the NRRS sampled in the in the contiguous 48 states. The data 
are the interpolated values for the geometric centroid of each county. An additional set of files using the same format given in Table 1 contain the TMY data for the Kenai Peninsula, Alaska (Homer Alaska), the only location in the NRRS not within the contiguous 48 states.

A comparison of the locations of the TMY measurement stations and NRRS sites shows that in most instances (about 90\%) there is a TMY site close to the NRRS monitoring locations. This is not surprising since the NRRS is a population weighted survey and the TMY sites are usually at or close to large urban centers. This implies that the NRRS-MET should be relatively accurate in predicting meteorological conditions at the NRRS sites.

\section{Discussion}

\section{Interpolation Reliability Tests.}

From an intuitive perspective, the results of Table 2 are not surprising. Those variables which vary only slowly in space and in time are more likely to be spatially predictable than those which have large variations locally. For example, average temperature varies quite smoothly with latitude. This is not the case for wind speed or wind direction, which is much more dependent on local geographic features. It is therefore not surprising that dry-bulb temperature would produce a good correlation, with a slope close to one and an intercept close to zero, whereas the statistics for the test would be poor for windspeed and even poorer for

wind direction. It is also not surprising that standard deviations of the weather variables over a month's time would not be predicted accurately since local geographical features are more likely to affect variability within a given time frame.

The results of this crude analysis of the reliability of the interpolation technique for this data set are not intended to provide an absolute measure of the quality of the interpolated values. However, it should provide a basis by which one can decide which variables and which of their statistics are reliable enough to use. The ultimate test, however, will be in the predictive power of these data when they are used in their intended application, e.g., for prediction of indoor pollutant concentrations.

As mentioned above, values in the database for meteorological data at locations near the actual measurement sites are more likely to reflect reality. Additionally, interpolated values are probably more 
accurate for regions where geographic and meteorological conditions are more homogeneous. For example the Great Plains/Midwestern U.S. are probably more likely to have accurate interpolated values than those for the coastal regions.

\section{Example of the Use of the Meteorological Database: Mapping of Meteorological Variables.}

Figure 3 is a contour map of annual heating infiltration degree days $\left({ }^{\circ} \mathrm{F}\right)$ in the United States. The contour lines were derived through interpolation of the calculated IDD values from the 208 TMY sites, using a commercially available computer graphics program. Such a map is useful for calculating building energy load due to air infiltration in different climate zones, and is similar to those from efforts in support of infiltration standards (ASHRAE, 1988 and Sherman, 1986).

\section{Example of the Use of the Meteorological Database: Statistical Modeling of Indoor Radon Concentrations.}

In research focused on determining the geographic distribution of indoor radon levels throughout the U.S., modeling approaches have been taken to assess what measurable factors have the potential of having a significant effect on indoor radon levels. One example of such a modeling approach is presented by Revzan et al. (1996), who examined correlations between geophysical, meteorological, and housing variables and indoor radon concentration data collected by the EPA in a national survey (the NRRS). This approach attempts to account for variability in mean indoor radon concentrations among counties of the contiguous 48 states using a mixed-effects statistical model (Gelman and Rubin, 1992). The response variable used in the analysis consists of 5027 mean living-area radon concentrations in 116 counties collected from one-year alpha-track measurements. Explanatory variables used in the model were taken from the NRRS (information on house characteristics), the USGS (soil and geological information for each house, including a value for soil uranium content), and the LBNL meteorological database. The details of this analysis will not be repeated here, but the results are informative: $64 \%$ of the variability among counties is explained by the model. The two most influential explanatory variables in the model are soil uranium content and the county prediction for annual heating IDD from the meteorological database. The regression coefficients for 
these variables, which had been normalized, are $0.97 \pm 0.18$ and $1.22 \pm 0.23$, respectively. The interpretation of these results is that, after adjusting for building construction characteristics, local geology and soil variability, and county variability, heating IDD is as strong a predictor of indoor radon concentrations from the NRRS as soil uranium concentrations.

\section{Accessing the Database}

Both the complete set of data for all county centroids (LBNL-MET) and the NRRS-MET subset are available to the scientific community through the World Wide Web at the LBNL-MET home page (at the URL address http://www.eande.gov/IEP/high-radon). These files may be accessed and copied by anyone with access to the internet.

The LBNL-MET database consists of one set of compressed files, whereas the NRRS-MET database consists of two sets of files. The format of all the files is the same. Both databases contain the meteorological data for the contiguous 48 states (file extension "ct", or "rn", for LBNL and NRRS, respectively). The second set, in the NRRS-MET database contains the data for the Kenai Peninsula (file extension "ak"). All files contain longitude, latitude, state, county, and FIPS entries in addition to the statistics of interest. The FIPS value consists of the state FIP times 1000 added to the county FIP. Using this scheme, each county has a unique identification expressed in a single number. The files are contained in a self-unpacking executable file readable by an IBM compatible personal computer. Descriptions of the data files and directions for unpacking them are available in a text file called "README" which can be viewed on the LBNL-MET Home Page. 


\section{Acknowledgments}

The authors would like to thank Gee-Minn Chang, Philip N. Price, JoAnn Ten Brinke, and Xiaomin Liu for their review of this work.

This work was supported by the U.S. Environmental Protection Agency through Interagency Agreement DW89935055-01-5 with the Department of Energy (DOE). This work was also supported by the Director,

Office of Energy Research, Office of Health and Environmental Research, Health Effects and Life Sciences Research Division of DOE under contract DE-AC03-76SF00098.

\section{References}

ASHRAE (1988) Air Leakage Performance for Detached Single-Family Residential Buildings, ANSI/ASHRAE Standard 119-1988, American Society of Heating, Refrigerating and Air-Conditioning Engineers, Inc., Atlanta, GA

Gelman, A. Carlin, J., Stern, H., and Rubin, D. (1995) Bayesian Data Analysis. Chapman and Hall, New York, NY.

Marcinowski, F., Lucas, R.M., and Yeager, W.M. (1994) "National and Regional Distributions of Airborne Radon-222 Concentrations in United-States Homes," Health Physics, 66:6,699-706.

Nazaroff, W.W., Moed, B.A., and Sextro, R.G.(1988). "Soil as a source of indoor radon: Generation, migration, and entry." In: Nazaroff, W.W. and Nero, A.V. Jr. (Eds.), Radon and Its Decay Products in Indoor Air. Wiley-Interscience, New York, N.Y., 57-112.

Nero, A.V. and Nazaroff, W.W. (1984). "Characterising the source of radon indoors." Radiat. Prot. Dosim. 7, 23-39.

Nero, A.V., Schwehr, M.B., Nazaroff, W.W., and Revzan, K.L. (1986). "Distribution of airborne radon-222 concentrations in U.S. homes." Science 234, 992-997.

Nero, A.V., Leiden, S.M., Nolan, D.A., Price, P.N., Rein, S., Revzan, K.L., Wollenberg, H.R., and Gadgil, A.J. (1993). "Statistically-based methodologies for mapping of radon "actual" concentrations: The case of Minnesota." Radiat. Prot. Dosim 56, 215-219. 
NOAA (1981) Typical Meteorological Year Users Manual, TD-9734, Hourly Solar Radiation-Surface Meteorological Observations, National Oceanic and Aeronautic Administration, National Climatic Center, Asheville, NC

NOAA (1991) Comparative Climatic Data-Climatological Normals (1961-1991), National Oceanic and Aeronautic Administration, National Climatic Center, Asheville, NC

Price, P.N., Nero, A.V., and Gelman A. (1995) Bayesian Prediction of mean indoor radon concentrations for Minnesota Counties, Report Number LBL-35818, Lawrence Berkeley National Laboratory, Berkeley, CA. In press, Health Physics, September 1995.

Revzan, K.L., Price, P.N., and Nero, A.V. (1996) Bayesian Analysis of the Relationship between Indoor Radon Concentrations and Predictive Variables in U.S. Houses, Lawrence Berkeley Laboratory Report Number LBL-38194, Lawrence Berkeley National Laboratory, Berkeley, CA.

Sherman, M. (1986) Exegesis of Proposed ASHRAE Standard 119: Air Leakage Performance for Detached Single-Family Residential Buildings, Lawrence Berkeley Laboratory Report Number LBL21040, Lawrence Berkeley National Laboratory, Berkeley, CA.

U.S. Bureau of Census (1991) TIGER/Line Files from U.S. 1990 Census. The U.S. Bureau of Census, Washington, DC 
Table 1 LBNL-MET Meteorological Variables and Summary Statistics.

\begin{tabular}{|c|c|c|c|}
\hline Meteorological variable & Statistic (units of meteorological data) & Meteorological variable & Statistic (units of meteorological data) \\
\hline Hours of precipitation & $\begin{array}{l}\text { monthly hours with no precipitation (hours) } \\
\text { monthly hours with rain (hours) } \\
\text { monthly hours with rain or snow (hours) } \\
\text { monthly hours with snow (hours) }\end{array}$ & \multirow[t]{4}{*}{ Dewpoint temperature } & $\begin{array}{l}\text { AM for month }\left({ }^{\circ} \mathrm{F}\right) \\
\text { ASD for month }\left({ }^{\circ} \mathrm{F}\right) \\
\text { monthly daytime } A M\left({ }^{\circ} \mathrm{F}\right) \\
\text { ASD diurnal swing }\left({ }^{\circ} \mathrm{F}\right)\end{array}$ \\
\hline Infiltration degree days & $\begin{array}{l}\text { monthly IDD ( }{ }^{\circ} \mathrm{F} \text {-day) } \\
\text { monthly cooling IDD ( }{ }^{\circ} \mathrm{F} \text {-day) } \\
\text { monthly heating IDD ( }{ }^{\circ} \mathrm{F} \text {-day) }\end{array}$ & & $\begin{array}{l}\text { monthly average diurnal swing } \\
\text { ASD daytime for month }\left({ }^{\circ} \mathrm{F}\right) \\
\text { average hourly swing for month }\left({ }^{\circ} \mathrm{F}\right)\end{array}$ \\
\hline Precipitation & monthly AM (inches) & & maximum for month $\left({ }^{\circ} \mathrm{F}\right)$ \\
\hline \multirow[t]{2}{*}{ Barometric Pressure } & $\begin{array}{l}\text { AM for month (psia) } \\
\text { ASD for month (psia) } \\
\text { monthly daytime AM (psia) }\end{array}$ & & $\begin{array}{l}\text { minimum for month }\left({ }^{\circ} \mathrm{F}\right) \\
\text { monthly daytime } A M\left({ }^{\circ} \mathrm{F}\right) \\
\text { ASD nighttime for month }\left({ }^{\circ} \mathrm{F}\right)\end{array}$ \\
\hline & $\begin{array}{l}\text { ASD diurnal swing (psia) } \\
\text { monthly average diurnal swing } \\
\text { ASD daytime for month (psia) } \\
\text { average hourly swing for month (psia) } \\
\text { maximum for month (psia) } \\
\text { minimum for month (psia) } \\
\text { monthly daytime AM (psia) } \\
\text { ASD nighttime for month (psia) }\end{array}$ & Wind direction & $\begin{array}{l}\text { east (hours) } \\
\text { north (hours) } \\
\text { northeast (hours) } \\
\text { west (hours) } \\
\text { south (hours) } \\
\text { southeast (hours) } \\
\text { southwest (hours) } \\
\text { west (hours) }\end{array}$ \\
\hline Dry bulb temperature & $\begin{array}{l}\text { AM for month }\left({ }^{\circ} \mathrm{F}\right) \\
\text { ASD for month }\left({ }^{\circ} \mathrm{F}\right) \\
\text { monthly daytime AM }\left({ }^{\circ} \mathrm{F}\right) \\
\text { ASD diumal swing }\left({ }^{\circ} \mathrm{F}\right) \\
\text { monthly average diurnal swing } \\
\text { ASD daytime for month }\left({ }^{\circ} \mathrm{F}\right) \\
\text { average hourly swing for month }\left({ }^{\circ} \mathrm{F}\right) \\
\text { maximum for month }\left({ }^{\circ} \mathrm{F}\right) \\
\text { minimum for month }\left({ }^{\circ} \mathrm{F}\right) \\
\text { monthly daytime } \mathrm{AM}\left({ }^{\circ} \mathrm{F}\right) \\
\text { ASD nighttime for month }\left({ }^{\circ} \mathrm{F}\right)\end{array}$ & Wind Speed & $\begin{array}{l}\text { AM for month }(\mathrm{m} / \mathrm{s}) \\
\text { ASD for month }(\mathrm{m} / \mathrm{s}) \\
\text { monthly daytime AM }(\mathrm{m} / \mathrm{s}) \\
\text { ASD diurnal swing }(\mathrm{m} / \mathrm{s}) \\
\text { monthly average diurnal swing } \\
\text { ASD daytime for month }(\mathrm{m} / \mathrm{s}) \\
\text { average hourly swing for month }(\mathrm{m} / \mathrm{s}) \\
\text { maximum for month }(\mathrm{m} / \mathrm{s}) \\
\text { minimum for month }(\mathrm{m} / \mathrm{s}) \\
\text { monthly daytime AM }(\mathrm{m} / \mathrm{s}) \\
\text { ASD nighttime for month }(\mathrm{m} / \mathrm{s})\end{array}$ \\
\hline
\end{tabular}


Table 2. Reliability Testing Results for the LBNL Meteorological Database.

\begin{tabular}{|c|c|c|c|c|c|}
\hline \multirow[b]{3}{*}{ VARIABLE/STATISTIC } & \multirow{3}{*}{$\begin{array}{l}\text { MULTIPLE } \\
\text { R-SQUARE }\end{array}$} & \multicolumn{2}{|c|}{ INTERCEPT } & \multicolumn{2}{|c|}{ SLOPE } \\
\hline & & & STANDARD & & STANDARD \\
\hline & & COEFFICIENT & ERROR & COEFFICIENT & ERROR \\
\hline \multicolumn{6}{|c|}{ INFILTRATION DEGREE DAYS ${ }^{\mathrm{a}}$} \\
\hline Total & 0.906 & 17.49 & 47.21 & 1.02 & 0.03 \\
\hline Heating & 0.752 & 0.02 & 0.15 & 1.06 & 0.06 \\
\hline Cooling & 0.891 & 49.26 & 48.44 & 0.97 & 0.04 \\
\hline \multicolumn{6}{|l|}{ PRECIPITATION } \\
\hline January & 0.777 & -0.04 & 0.17 & 1.02 & 0.06 \\
\hline February & 0.550 & 0.65 & 0.19 & 0.67 & 0.06 \\
\hline March & 0.446 & 0.67 & 0.31 & 0.85 & 0.10 \\
\hline April & 0.550 & 0.38 & 0.27 & 0.93 & 0.09 \\
\hline May & 0.900 & 0.20 & 0.11 & 0.94 & 0.03 \\
\hline June & 0.846 & 0.31 & 0.15 & 0.88 & 0.04 \\
\hline July & 0.930 & -0.03 & 0.10 & 1.02 & 0.03 \\
\hline August & 0.799 & 0.31 & 0.17 & 0.91 & 0.05 \\
\hline September & 0.856 & 0.43 & 0.14 & 0.88 & 0.04 \\
\hline October & 0.832 & 0.05 & 0.12 & 0.99 & 0.05 \\
\hline November & 0.670 & 0.44 & 0.19 & 0.83 & 0.06 \\
\hline December & 0.414 & 0.26 & 0.37 & 1.06 & 0.13 \\
\hline \multicolumn{6}{|l|}{ HOURS OF PRECIPITATION $^{\mathrm{a}}$} \\
\hline rain & 0.081 & 10.67 & 9.00 & 0.49 & 0.17 \\
\hline snow & 0.152 & 25.20 & 4.24 & 0.29 & 0.07 \\
\hline rain or snow & 0.265 & 42.80 & 7.08 & 0.50 & 0.09 \\
\hline dry & $2 e-04$ & 504.29 & 65.95 & 0.02 & 0.11 \\
\hline \multicolumn{6}{|l|}{ WIND DIRECTION $^{a}$} \\
\hline North & 0.006 & 129.96 & 15.55 & 0.07 & 0.10 \\
\hline Northeast & $3 e-04$ & 64.81 & 9.17 & 0.02 & 0.12 \\
\hline East & 0.008 & 44.52 & 7.57 & 0.10 & 0.12 \\
\hline Southeast & 0.027 & 49.20 & 13.29 & 0.25 & 0.15 \\
\hline South & 0.031 & 75.18 & 10.90 & 0.17 & 0.10 \\
\hline Southwest & 0.153 & 63.18 & 11.76 & 0.41 & 0.10 \\
\hline West & 0.002 & 86.02 & 11.59 & 0.04 & 0.10 \\
\hline Northwest & 0.133 & 74.61 & 13.26 & 0.42 & 0.11 \\
\hline
\end{tabular}


Table 2. Reliability Testing Results for the LBNL Meteorological Database (Continued).

\begin{tabular}{|c|c|c|c|c|c|}
\hline \multirow[b]{3}{*}{ VARIABLE/STATISTIC } & \multirow{3}{*}{$\begin{array}{l}\text { MULTIPLE } \\
\text { R-SQUARE }\end{array}$} & \multicolumn{2}{|c|}{ INTERCEPT } & \multicolumn{2}{|c|}{ SLOPE } \\
\hline & & & STANDARD & & STANDARD \\
\hline & & COEFFICIENT & ERROR & COEFFICIENT & ERROR \\
\hline \multicolumn{6}{|l|}{ BAROMETRIC PRESSURE ${ }^{a}$} \\
\hline Monthly Average Arithmetic Mean & 0.074 & 7.63 & 2.60 & 0.48 & 0.18 \\
\hline Monthly Average Standard Deviation & 0.049 & 0.10 & 0.01 & 0.11 & 0.05 \\
\hline Monthly Daytime Arithmetic Mean & 0.357 & 4.73 & 1.39 & 0.68 & 0.09 \\
\hline Monthly Daytime Standard Deviation & 0.380 & 0.05 & 0.01 & 0.62 & 0.08 \\
\hline Monthly Night Arithmetic Mean & 0.182 & 4.09 & 2.33 & 0.72 & 0.16 \\
\hline Monthly Nighttime Standard Deviation & 0.130 & 0.02 & 0.03 & 0.85 & 0.23 \\
\hline Diurnal Swing Arithmetic Mean & 0.346 & 0.05 & 0.01 & 0.60 & 0.08 \\
\hline Diurnal Swing Standard Deviation & $6 e-04$ & 0.05 & 0.01 & 0.01 & 0.03 \\
\hline Maximum & 0.019 & 7.61 & 5.47 & 0.49 & 0.36 \\
\hline Minimum & 0.011 & 8.99 & 5.34 & 0.38 & 0.37 \\
\hline Average Hourly Swing & 0.004 & 0.01 & 0.00 & 0.045 & 0.08 \\
\hline \multicolumn{6}{|l|}{ DEW POINT ${ }^{a}$} \\
\hline Monthly Average Arithmetic Mean & 0.785 & -2.07 & 1.46 & 1.04 & 0.06 \\
\hline Monthly Average Standard Deviation & 0.220 & 6.42 & 1.22 & 0.50 & 0.10 \\
\hline Monthly Daytime Arithmetic Mean & 0.818 & -1.61 & 1.31 & 1.03 & 0.05 \\
\hline Monthly Daytime Standard Deviation & 0.304 & 5.17 & 1.13 & 0.57 & 0.09 \\
\hline Monthly Night Arithmetic Mean & 0.907 & 0.46 & 0.82 & 0.97 & 0.03 \\
\hline Monthly Nighttime Standard Deviation & 0.396 & 3.81 & 1.11 & 0.68 & 0.09 \\
\hline Diurnal Swing Arithmetic Mean & 0.179 & 7.68 & 1.33 & 0.43 & 0.10 \\
\hline Diurnal Swing Standard Deviation & 0.200 & 3.79 & 0.69 & 0.45 & 0.09 \\
\hline Maximum & 0.699 & 5.37 & 3.01 & 0.89 & 0.06 \\
\hline Minimum & 0.676 & -0.48 & 1.10 & 0.83 & 0.06 \\
\hline Average Hourly Swing & 0.021 & 1.01 & 0.14 & 0.15 & 0.10 \\
\hline \multicolumn{6}{|l|}{ DRY BULB TEMPERATURE ${ }^{\mathrm{a}}$} \\
\hline Monthly Average Arithmetic Mean & 0.950 & 1.15 & 0.82 & 0.97 & 0.02 \\
\hline Monthly Average Standard Deviation & 0.323 & 2.86 & 1.35 & 0.78 & 0.12 \\
\hline Monthly Daytime Arithmetic Mean & 0.896 & -0.54 & 1.28 . & 0.10 & 0.03 \\
\hline Monthly Daytime Standard Deviation & 0.306 & 2.40 & 1.53 & 0.81 & 0.13 \\
\hline Monthly Night Arithmetic Mean & 0.906 & -0.68 & 1.11 & 1.01 & 0.03 \\
\hline Monthly Nighttime Standard Deviation & 0.568 & 1.47 & 0.91 & 0.87 & 0.08 \\
\hline Diurnal Swing Arithmetic Mean & 0.458 & 3.70 & 1.66 & 0.79 & 0.09 \\
\hline Diurnal Swing Standard Deviation & 0.173 & 3.55 & 0.87 & 0.52 & 0.12 \\
\hline Maximum & 0.774 & 5.98 & 3.19 & 0.91 & 0.05 \\
\hline Minimum & 0.803 & 0.35 & 0.94 & 0.90 & 0.05 \\
\hline Average Hourly Swing & 0.339 & 0.50 & 0.14 & 0.63 & 0.09 \\
\hline
\end{tabular}


Table 2. Reliability Testing Results for the LBNL Meteorological Database (Continued).

\begin{tabular}{|c|c|c|c|c|c|}
\hline \multirow[b]{2}{*}{ VARIABLE/STATISTIC } & \multirow[b]{2}{*}{$\begin{array}{l}\text { MULTIPLE } \\
\text { R-SQUARE } \\
\end{array}$} & \multicolumn{2}{|c|}{ INTERCEPT } & \multicolumn{2}{|c|}{ SLOPE } \\
\hline & & COEFFICIENT & $\begin{array}{c}\text { STANDARD } \\
\text { ERROR }\end{array}$ & COEFFICIENT & $\begin{array}{l}\text { STANDARD } \\
\text { ERROR }\end{array}$ \\
\hline \multicolumn{6}{|l|}{ WIND SPEED ${ }^{a}$} \\
\hline Monthly Average Arithmetic Mean & 0.114 & 2.50 & 0.54 & 0.41 & 0.12 \\
\hline Monthly Average Standard Deviation & 0.018 & 2.05 & 0.22 & 0.12 & 0.09 \\
\hline Monthly Daytime Arithmetic Mean & 0.023 & 4.02 & 0.57 & 0.17 & 0.11 \\
\hline Monthly Daytime Standard Deviation & 0.023 & 1.97 & 0.27 & 0.15 & 0.10 \\
\hline Monthly Night Arithmetic Mean & 0.093 & 2.73 & 0.41 & 0.30 & 0.10 \\
\hline Monthly Nighttime Standard Deviation & 0.021 & & 0.25 & 0.15 & 0.11 \\
\hline Diurnal Swing Arithmetic Mean & 0.079 & 3.86 & 0.67 & 0.32 & 0.11 \\
\hline Diurnal Swing Standard Deviation & 0.138 & 1.50 & 0.19 & 0.33 & 0.08 \\
\hline Maximum & 0.055 & 10.67 & 1.43 & 0.25 & 0.11 \\
\hline Minimum & 0.009 & 1.05 & 0.03 & 0.09 & 0.10 \\
\hline Average Hourly Swing & 0.004 & 0.83 & 0.10 & -0.07 & 0.12 \\
\hline
\end{tabular}

${ }^{\mathrm{a}}$ Regression of interpolated values from randomly selected meteorological measurement sites against actual measured values for those sites for the month of January. 


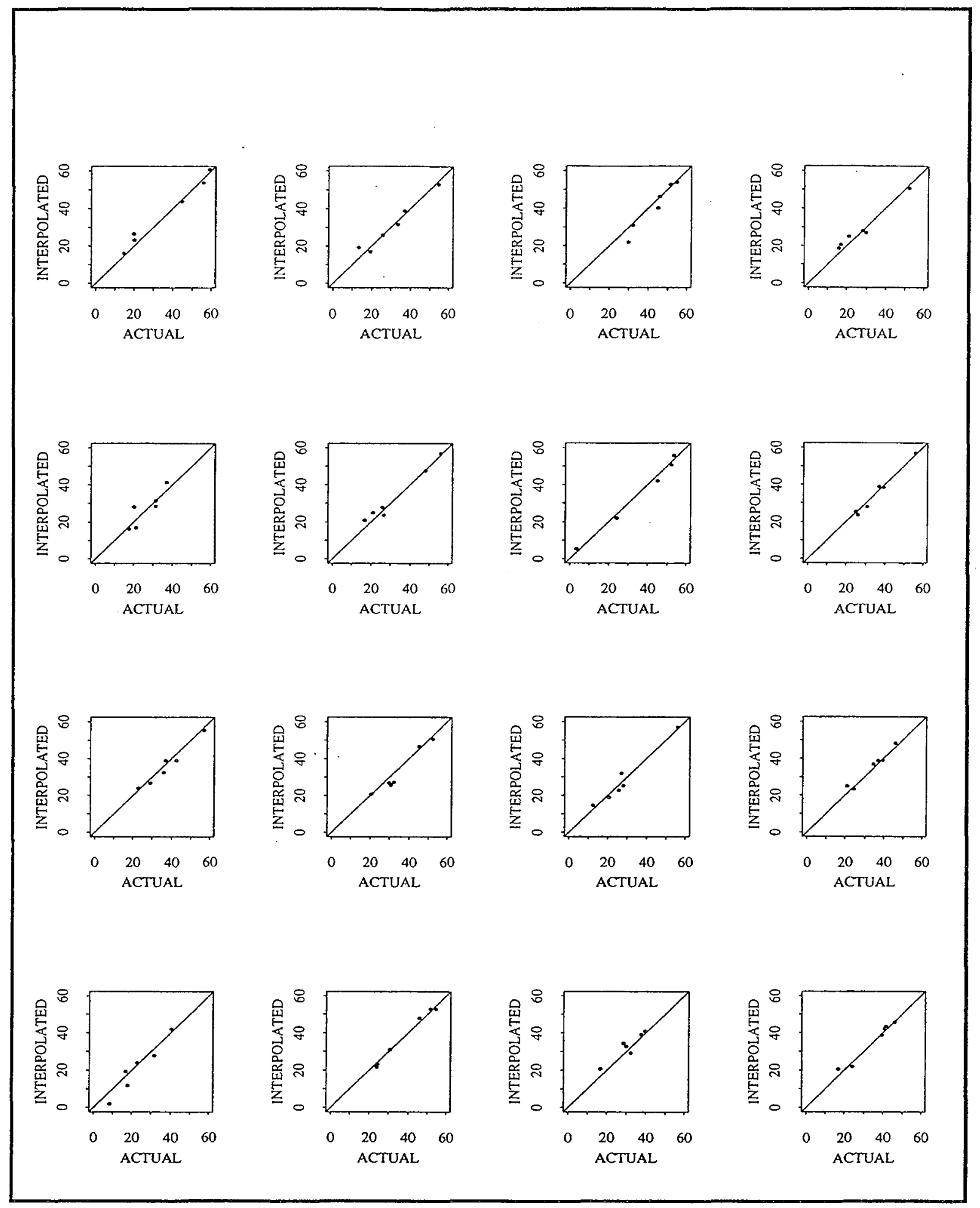

Figure 1. Sixteen sets of randomly selected "interpolated" average dry-bulb temperatures ( $\left.{ }^{\circ} \mathrm{F}\right)$ vs. "actual" average dry-bulb temperatures for the month of January. The line represents perfect correlation (slope $=1$ and intercept $=0$ ). 


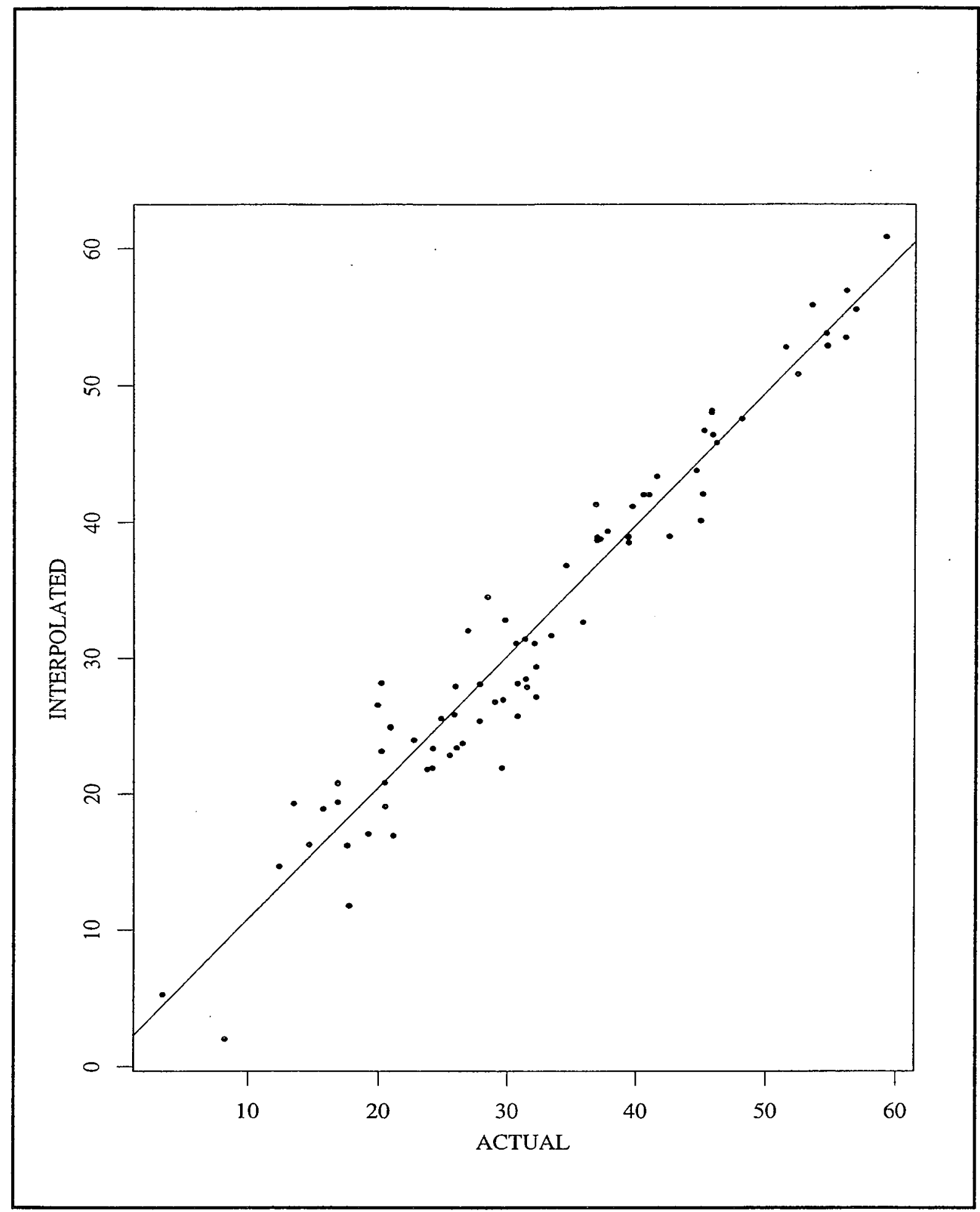

Figure 2. Composite of (Figure 1) 16 sets of 6 pairs of "interpolated" average dry-bulb temperatures $\left({ }^{\circ} \mathrm{F}\right)$ vs. "actual" average dry-bulb temperatures for the month of January. The line is the least-squares best-fit to the data $\left(\mathrm{R}^{2}=0.950\right.$, see Table 2 : monthly-average arithmetic mean dry-bulb temperature). 


\section{Annual Heating Infiltration Degree Days}

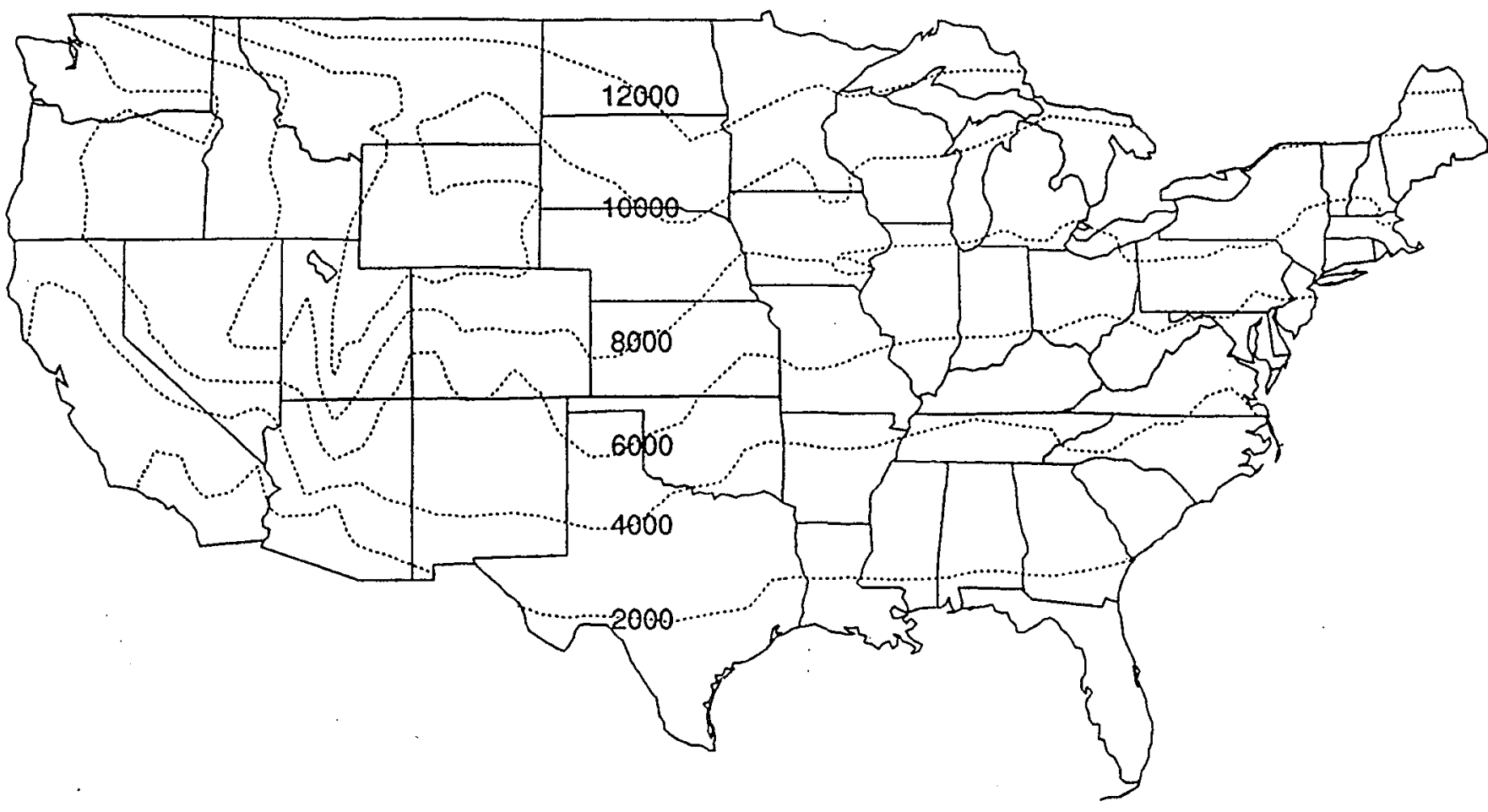

Figure 3. A contour map of annual heating infiltration degree days (IDD, $\left.{ }^{\circ} \mathrm{F}\right)$ in the United States. The contour lines were derived through interpolation of the calculated IDD values from the 208 TMY sites. 
APPENDIX I.

Equations for selected statistics used in the LBNL Meteorological Database

1) diurnal swing:

$S_{\text {diurnàl }}=\frac{\sum_{i=1}^{N} T_{d a y_{i}}-T_{\text {night }_{i}}}{N}$

where:

$S_{\text {diurnal }}=$ average diurnal swing;

$T_{d a y_{i}}=$ average daytime temperature on day $i$,

$T_{\text {night }_{i}}=$ average nighttime temperature on day $i$,

$N=$ number of days in month.

2) average hourly swing:

$S_{\text {hourly }}=\frac{\sum_{i=1}^{N^{\prime}}\left|T_{i}-T_{i-1}\right|}{N^{\prime}}$

where:

$S_{\text {hourly }}=$ average hourly swing,

$T_{i}=$ temperature at hour $i$,

$T_{i-1}=$ temperature at hour $i-1$,

$N^{\prime}=$ number of days in month. 

